\title{
1. EXPLANATORY NOTES, DEEP SEA DRILLING PROJECT LEG 95, NEW JERSEY TRANSECT ${ }^{1}$
}

\author{
Amanda A. Palmer, Ocean Drilling Program, Texas A\&M University ${ }^{2}$
}

These explanatory notes are intended to aid the reader in understanding the Leg 95 site chapters that follow. Although the Leg 95 shipboard party generally followed standard Deep Sea Drilling Project (DSDP) procedures, every DSDP cruise has procedural peculiarities that result from the personalities and interests of the shipboard scientists and from the overall scientific objectives. This chapter outlines standard DSDP shipboard procedures and details Leg 95 deviations from them.

\section{RESPONSIBILITY OF AUTHORSHIP}

Site summary chapters are coauthored by the entire shipboard scientific party; ultimate responsibility for their content lies with the two Co-Chief Scientists. The Leg 95 site chapters are organized into the following sections, with authors' names listed alphabetically in parentheses:

Site Summary (Poag, Watts)

Geologic Setting and Objectives (Poag, Watts)

Operations (Huey)

Sediment Lithology (Cousin, Mountain, Schreiber, Thein)

Biostratigraphy (Hart, Miller, Palmer, Valentine)

Sedimentation Rates and Subsidence History (Hart, Miller, Palmer, Valentine, Watts)

Geochemistry (Nakamura, Tarafa)

Physical Properties (Wilkins)

Downhole Logging (Goldberg)

Seismostratigraphy (Poag)

Summary and Conclusions (Poag, Watts)

Paul Schiffelbein acted as Staff Representative during the cruise and as Science Editor for the site chapters; Amanda Palmer was Science Editor for the special studies chapters.

Data and preliminary interpretations in the site chapters reflect knowledge gleaned only from shipboard and very initial postcruise analyses. Results of the more detailed shore-based work presented in the special studies chapters in the second portion of this volume supercede, in some cases, the initial interpretations expressed in the preliminary site chapters.

Although drilling at Site 603 occurred during Leg 95, only results from Sites 612 and 613 are reported in this volume. All data and interpretations regarding Site 603 appear in the Leg 93 cruise volume (van Hinte, Wise, et al., in press).

\footnotetext{
${ }^{1}$ Poag, C. W., Watts, A. B., et al., Init. Repts. DSDP, 95: Washington (U.S. Govt. Printing Office).

2 Address: Ocean Drilling Program, Texas A\&M University, 500 University Drive West, College Station, TX 77843.
}

\section{SURVEY AND DRILLING DATA}

The survey data used for specific site selections are discussed in each site chapter. En route between sites, continuous observations were made of depth, magnetic field, and sub-bottom structure. Short surveys using a precision echo sounder, seismic profiler, and magnetometer were made on Glomar Challenger before dropping the beacon.

The seismic-profiling system consisted of either an 80 -in. ${ }^{3}$ water gun or two Bolt air guns, a Scripps-designed hydrophone array, Bolt amplifiers, two bandpass filters, and two EDO recorders, usually recording at two different filter settings.

Depths were continuously recorded underway on a Gifft precision graphic recorder. The depths were read on the basis of an assumed $1463 \mathrm{~m} / \mathrm{s}$ sound velocity. The water depth (in meters) at each site was corrected (1) according to the tables of Matthews (1939) and (2) for the depth of the hull transducer $(6 \mathrm{~m})$ below sea level. In addition, depths referred to the drilling platform level are assumed to be $10 \mathrm{~m}$ above the water line.

\section{DRILLING CHARACTERISTICS}

Because water circulation down the hole is open, cuttings are lost onto the seafloor and cannot be examined. The only available information about sedimentary stratification in uncored or unrecovered intervals, other than from seismic data or wireline logging results, is from an examination of the behavior of the drill string as observed on the drill platform. The harder the layer being drilled, the slower and more difficult it usually is to penetrate. There are, however, a number of other factors that determine the rate of penetration, so it is not always possible to relate this directly to the hardness of the layers. The parameters of bit weight and revolutions per minute also influence the rate of penetration and are recorded on the drilling recorder.

\section{DRILLING DEFORMATION}

When cores are spilt, many show signs of significant sediment disturbance. Such disturbance includes the concave-downward appearance of originally horizontal bands, the haphazard mixing of lumps of different lithologies, and the near-fluid state of some sediments recovered from tens to hundreds of meters below the seafloor. Core deformation probably occurs during one of three different steps at which the core can suffer stresses sufficient to alter its physical characteristics: cutting, retrieval (with accompanying changes in pressure and temperature), and core handling. 


\section{SHIPBOARD SCIENTIFIC PROCEDURES}

\section{Numbering of Sites, Holes, Cores, and Samples}

DSDP drill sites are numbered consecutively from the first site drilled by Glomar Challenger in 1968. Site numbers are slightly different from hole numbers. A site number refers to one or more holes drilled while the ship is positioned over a single acoustic beacon. These holes can be within a radius as large as $900 \mathrm{~m}$ from the beacon. Several holes may be drilled at a single site by pulling the drill pipe above the seafloor (out of one hole), moving the ship $20 \mathrm{~m}$ or more from the previous hole, and then drilling another hole.

The first (or only) hole drilled at a site takes the site number. A letter suffix distinguishes each additional hole at the same site. For example: the first hole takes only the site number; the second takes the site number with suffix A; the third takes the site number with suffifx B, and so forth. It is important, for sampling purposes, to distinguish the holes drilled at a site because recovered sediments or rocks from cores with the same site number, but from different holes, usually do not come from equivalent positions in the stratigraphic column.

The cored interval is measured in meters below the seafloor. The depth interval of an individual core is the depth below seafloor that the coring operation began to the depth that the coring operation ended. Each coring interval is generally $9.5 \mathrm{~m}$ long, which is the nominal length of a core barrel. The coring interval may, however, be shorter. "Cored intervals" are not necessarily adjacent to each other, but may be separated by "drilled intervals." In soft sediment, the drill string can be "washed ahead" with the core barrel in place, but not recovering sediment, by pumping water or drilling fluid down the pipe at high pressure to wash the sediment out of the way of the bit. If thin, hard rock layers are present, however, it is possible to get "spotty" sampling of these resistant layers within the washed interval, producing a cored interval representing more than $9.5 \mathrm{~m}$ ("wash core").

Cores taken from a hole are numbered serially from the top of the hole downward. Full recovery for a single core is normally $9.3 \mathrm{~m}$ of sediment or rock, which is in a plastic liner (6.6 cm ID), plus about a 0.2 -m-long sample (without a plastic liner) in a core catcher. The core catcher is a device at the bottom of the core barrel that prevents the core from sliding out while the barrel is being retrieved from the hole. The sediment core, which is in the plastic liner, is then cut into 1.5 -m-long sections that are numbered serially from the top of the sediment core (Fig. 1). When full recovery is obtained, the sections are numbered from 1 through 7 , the last section being shorter that $1.5 \mathrm{~m}$. The core catcher sample is placed below the last section when the core is described, labeled "Core Catcher" (CC), and is treated as a separate section.

When recovery is less than $100 \%$, and if the sediment is contiguous, the recovered sediment is conventionally placed at the top of the cored interval, and then $1.5-\mathrm{m}$ long sections are numbered serially, starting with Section 1 at the top. There will be as many sections as needed to accommodate the length of the core recovered (Fig. 1); for example, $3 \mathrm{~m}$ of core sample in a plastic liner will be divided into two 1.5-m-long sections. Sections are cut starting at the top of the recovered sediment, and the last section can be shorter than the normal 1.5-m length. Furthermore, with less than full recovery the original stratigraphic position of the sediment in the cored interval is unknown; we conventionally assign the top of the recovered sediment to the top of the cored interval. This is done for convenience in data handling and for consistency. If recovery is less than $100 \%$ and core fragments are separated, the sections are still numbered serially and the void spaces are preserved while cutting the 1.5-m sections (Fig. 1).

Samples from core sections are designated by distances in centimeters from the top of each section to the top and bottom of the sample interval in that section. A full identification number for a sample consists of the following information: (1) leg, (2) site, (3) hole, (4) core, (5) section, and (6) interval in centimeters. For example, the sample identification number "95-612-6-3, 98-100 $\mathrm{cm}$ " means that a sample was taken between 98 and 100 $\mathrm{cm}$ form the top of Section 3 of Core 6, from the first hole drilled at Site 612 during Leg 95. A sample from the core catcher of this core might be designated " 95 612-6,CC (8-9 cm)".

The depth below the seafloor from which a sample numbered "95-612-6-3, 98-100 cm" was collected is the sum of the depth to the top of the cored interval for Core $6(40.6 \mathrm{~m})$ plus the $3 \mathrm{~m}$ included in Sections 1 and 2 (each $1.5 \mathrm{~m}$ long) plus the $98 \mathrm{~cm}$ below the top of Section 3. The sample in question is therefore from $44.58 \mathrm{~m}$ sub-bottom, which in principle is the sample sub-seafloor depth (sample requests should refer to a specific interval within a core section, rather than the depth below seafloor).

Two types of coring systems were used on the Glomar Challenger during Leg 95: (1) the standard DSDP rotary-coring system and (2) the Advanced Hydraulic Piston Coring/Extended Core Barrel (APC/XCB) system. Conventions regarding the cataloging of $\mathrm{APC} / \mathrm{XCB}$ core are the same as those for the rotary cores. A full APC/XCB core, therefore, consists of six sections, each $1.5 \mathrm{~m}$ long, a seventh section of variable length, and a core catcher as much as $0.2 \mathrm{~m}$ long. For details regarding the APC/ $\mathrm{XCB}$ operation, core orientation, and special $\mathrm{APC} / \mathrm{XCB}$ features, see Development and Engineering Technical Reports Nos. 12, 20, and 21 (available from the Deep Sea Drilling Project).

\section{HANDLING OF CORES}

Cores collected during Leg 95 were normally cut into $1.5-\mathrm{m}$ sections, capped and labeled; the sections were then brought into the shipboard core laboratory for processing. Continuous wet-bulk density determinations using the Gamma Ray Attenuation Porosity Evaluator (GRAPE) were made on most of the sections before they were split lengthwise.

The cores were then split longitudinally into "work" and "archive" halves with the wire cutter. The first measurements made on the work halves were compressionalwave velocity and vane-shear measurements. Samples sub- 

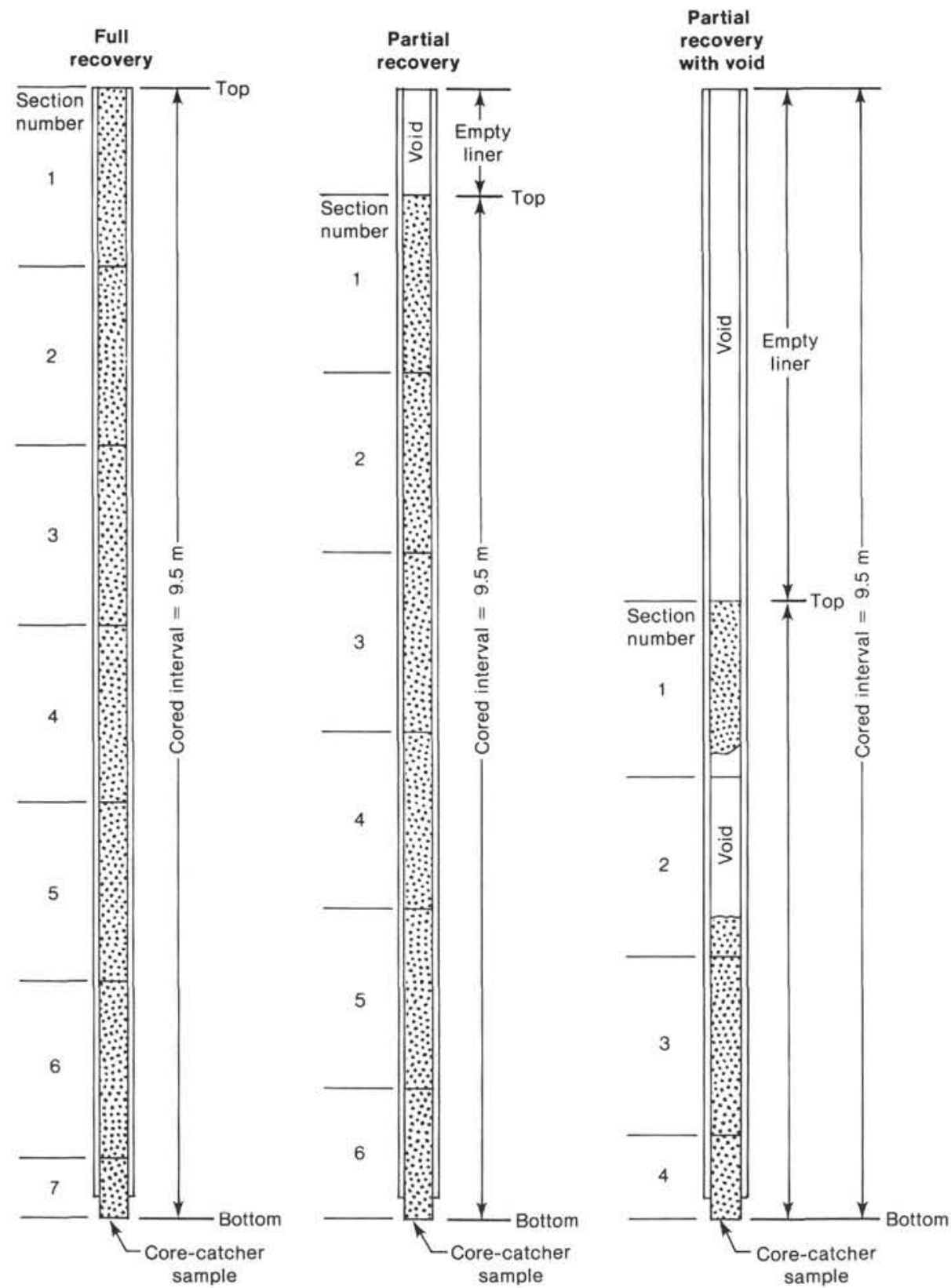

Figure 1. Diagram showing procedure for cutting and labeling of core sections. By convention, sediment from cores with only partial recovery is assumed to have come from the top of the cored interval.

sequently extracted from the work halves included those for (1) shipboard measurement of wet-bulk density by GRAPE and gravimetric techniques (Boyce, 1976), (2) shipboard measurement of calcium carbonate percentage with the carbonate bomb (Müller and Gastner, 1971), and (3) numerous shore-based geochemical, paleontological, paleomagnetic, geotechnical, sedimentologic, and petrologic studies.

The color, texture, structure, physical disturbance by the drill bit, and composition of each archive half were described in detail on standard visual core description sheets (one per section). One or more smear slides were made from the sediments recovered in each core and examined by petrographic microscope. The archive half of the core section was then photographed (both black and white prints and $35-\mathrm{mm}$ color slides).

After the cores were sampled and described, both the "work" and "archive" halves were maintained in cold storage aboard Glomar Challenger until they were transferred to the DSDP repository at the end of the cruise. Samples and whole core sections collected for organic geochemistry studies were frozen immediately on board ship and kept frozen. All Leg 95 cores are presently stored at the Ocean Drilling Program (ODP) East Coast Repository (Lamont-Doherty Geological Observatory).

Visual core description sheets, smear slide descriptions, paleontologic data, and carbonate bomb (percent $\mathrm{CaCO}_{3}$ ) determinations (all done aboard ship), provide 
the data for the summary core descriptions or "barrel sheets" presented at the end of each site chapter in this volume (Fig. 2). Locations of smear slide and carbonate bomb samples are shown with a symbol in the "Sample" column of these barrel sheets.

\section{DESCRIPTION OF SEDIMENTS}

\section{Sediments and Sedimentary Rocks Core Description Form}

\section{Drilling Disturbance}

Recovered materials, particularly soft sediment, may be extremely disturbed. This mechanical disturbance particularly results from the rotary coring technique, which uses a $25-\mathrm{cm}$-diameter bit with a 6.2 -cm-diameter opening for the core sample. Hydraulically piston-cored material tends to be less disturbed, but can include significant intervals of flow-in. Symbols for the five disturbance categories used for soft and firm sediment on Leg 95 are shown on the core description form in the column entitled "Drilling Disturbance" (Fig. 2).

The disturbance categories for soft sediments are defined as (1) Slightly deformed: bedding contacts are slightly bent. (2) Moderately deformed: bedding contacts have undergone extreme bowing. (3) Very deformed: bedding is completely disturbed or homogenized by drilling, in some cases showing symmetrical diapir-like structure. (4) Soupy: water-saturated intervals which have lost all aspects of original bedding.

The disturbance categories for hard sediments are defined as: (1) Pervasively fractured: indurated sediments broken into fragments in which original orientation is preserved or recognizable. (2) "Drilling biscuits": fragments are from the cored interval and are probably in the correct stratigraphic sequence (although they may not represent the entire section), but original orientation is totally lost; biscuits are often surrounded by a "drilling paste" formed by abrasion of biscuits against one another. (3) Breccia: indurated sediments are broken into angular fragments by the drilling process, perhaps along pre-existing fractures, and have lost their original orientation and stratigraphic position; may be completely mixed with drilling slurry.

\section{Sedimentary Structures}

It can be extremely difficult to distinguish between natural structures and structures created by the coring process in sediment cores. Where the origin of observed structures is in question, notes to that effect are included on the core description forms. Locations and types of structures appear as graphic symbols in the column entitled "Sedimentary Structures" on the core description form (Fig. 2). Figure 3 gives the key to the symbols used for sedimentary structures recognized in sediments recovered on Leg 95.

\section{Color}

Colors of the core samples were determined with Munsell Soil Color Charts. Colors were determined immediately after the cores were split while still wet.

\section{Lithology}

Recovered lithologies are represented on the core description forms by a single symbol or by a grouping of two or more symbols (Fig. 4) in the column entitled "Graphic Lithology" (Fig. 2). The symbols in a grouping correspond to end members of sediment constituents, such as clay or nannofossil ooze. The symbol for the terrigenous constituent(s) appear on the right-hand side of the column, the symbol for the biogenic constituent(s) on the left-hand side of the column. The abundance of any component approximately equals the percentage of the width of the graphic column its symbol occupies. For example the left $20 \%$ of the column may have a nannofossil ooze symbol, whereas the right $80 \%$ may have a clay symbol, indicating sediment composed of $80 \%$ clay and $20 \%$ nannofossils.

Because of the difference in the length-to-width ratio between the actual sediment core and the graphic lithologic column, it is not possible to reproduce structures and they appear in the core; in the graphic representation they are highly flattened and distorted.

\section{Shipboard Analyses}

Smear slide compositions and carbonate bomb analyses determined on board Glomar Challenger are listed below the written core description on the core description forms. The locations of these samples in the core are shown in the column entitled "Samples" (Fig. 2). Locations and intervals of whole core samples for organic geochemistry (OG), interstitial water (IW), and physical properties (PP) are also indicated in the column on the core description forms.

\section{Lithologic Classification of Sediments}

The basic classification system used on Leg 95 was devised by the former JOIDES Sedimentary Petrology and Physical Properties Panel (SP4), and adopted for the use by the JOIDES Planning Committee in March 1974.

The DSDP classification used by the Leg 95 sedimentologists is descriptive rather than generic, and categories are based on sediment parameters measured on board ship. Sediment names are those in common usage. A brief outline of the conventions and descriptive data used to construct this classification follows.

\section{Conventions and Descriptive Data}

In this classification scheme, composition and texture are the only criteria used to define the type of sediment or sedimentary rock recovered. Composition is more important for describing sediments deposited in the open ocean, while texture becomes significant for hemipelagic and nearshore sediments. Compositional and textural data come principally from visual estimates of component percentages in smear slides examined with a petrographic microscope. These data are estimates of areal abundance and size components on the slide and may differ somewhat from more accurate analyses of grain size, carbonate content, and mineralogy because of the very small sample used to make a smear slide. Past expe- 


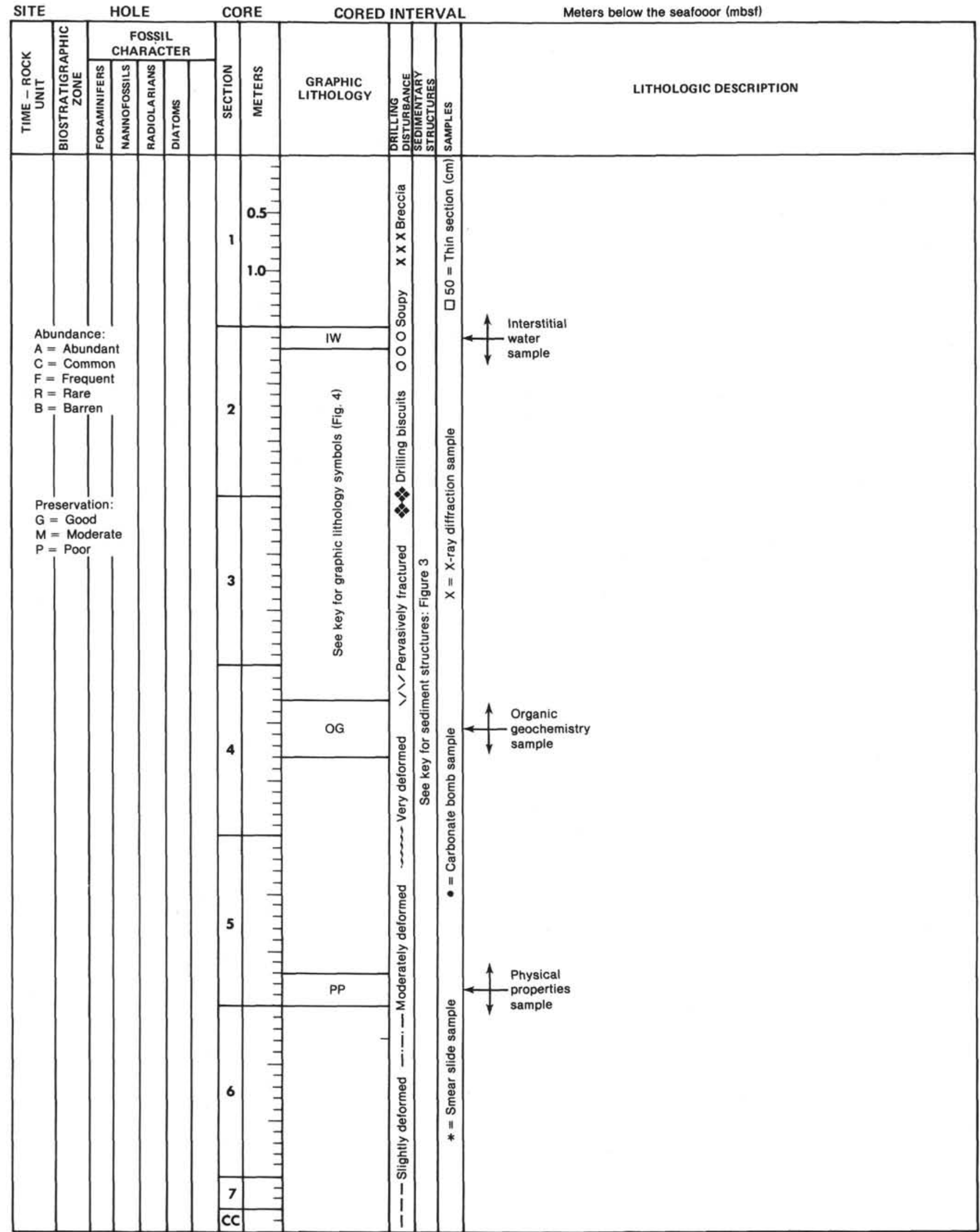

Figure 2. Sample core description form for sediments and sedimentary rocks ("barrel sheet"). 


Plauconite
Pyrite, disseminated

Figure 3. Standard symbols for sedimentary structures recognized in sediments recovered during Leg 95 . These symbols are shown in the "Sedimentary Structure" column of the DSDP core description forms (Fig. 2).

rience indicates that quantitative estimates of distinctive minor components are accurate to within 1 to $2 \%$, but that accuracy for major constituents is poorer, perhaps only to within $10 \%$. Smear-slide data are verified by carbonate-content data determined using the carbonate bomb available on board ship.

Where applicable, one or several modifiers are used in naming the type of sediment encountered. In all cases, the dominant component appears last in the name; minor components precede, with the least common constituent listed first. Minor constituents occurring in amounts less than $10 \%$ are not normally included in the name.

The degree of induration or lithification of the recovered sediment is reflected in the sediment name. Calcareous sediments and sedimentary rocks are divided into three categories of induration after Gealy et al. (1971): (1) "Oozes" are soft calcareous sediments with little strength that readily deform under the pressure of a finger or the broad blade of a spatula; (2) "Chalks" are firm, partially lithified calcareous oozes that are readily scratched with a fingernail or edge of a spatula; (3) "Limestones" are hard, well lithified and cemented calcareous sedimentary rocks that are resistant or impossible to scratch with a fingernail or edge of a spatula. Terrigenous sediments are called by the sediment name if the material is soft enough for the core to be split with a wire cutter (e.g., silty clay), or by the sediment name plus the suffix "stone" if the core must be cut with a band saw or diamond saw (e.g., silty claystone).

\section{Types of Sediments, Sedimentary Rocks, and Compositional Boundaries}

\section{Siliceous Biogenic Sediment}

Siliceous biogenic sediments contain common siliceous microfossils. They are distinguished from a calcareous category by a calcium carbonate content of less than $30 \%$.

There are two categories of siliceous biogenic sediments: (1) pelagic siliceous biogenic sediments, which contain greater than $70 \%$ siliceous microfossils and less than $30 \%$ silt and clay and (2) transitional siliceous biogenic sediments, which contain between 10 and $70 \%$ siliceous microfossils and greater than $30 \%$ silt and clay. Soft pelagic siliceous biogenic sediments are termed siliceous oozes (radiolarian ooze or diatom ooze, depending on the dominant fossil component). Hard pelagic siliceous biogenic sediments include radiolarite, porcellanite, diatomite, and chert. Soft transitional siliceous biogenic sediments with less than $50 \%$ siliceous microfossils are termed siliceous (or diatomaceous, if diatoms were the dominant fossil component) muds. Soft transitional siliceous biogenic sediments with greater than $50 \%$ siliceous microfossils are termed muddy siliceous (diatom) ooze.

A special category of siliceous sediments described on Leg 95 is an indeterminate mixture of clay and (variably) opal-A or opal-CT. This is illustrated in the graphic lithology column using a special symbol (Fig. 4).

\section{Calcareous Biogenic Sediment}

Calcareous biogenic sediment is distinguished from terrigenous sediment and siliceous biogenic sediment by a biogenic $\mathrm{CaCO}_{3}$ content in excess of $30 \%$. There are two classes: (1) pelagic-calcareous-biogenic sediment that contains 60 to $100 \%$ biogenic $\mathrm{CaCO}_{3}$ (less than $30 \%$ silt and clay) and (2) transitional-calcareous-biogenic sediment that contains 30 to $60 \% \mathrm{CaCO}_{3}$ (greater than $30 \%$ silt and clay).

\section{Terrigenous Sediments}

Terrigenous sediment is distinguished by a terrigenous component in excess of $30 \%$ and by siliceous and authigenic components each less than $10 \%$. Sediments in this category are subdivided into textural groups by macroscopic and/or smear slide estimation of the relative proportions of sand, silt, and clay (Fig. 5) using the size limits defined by Wentworth (1922) (Fig. 6). 
Pelagic biogenic calcareous sediments

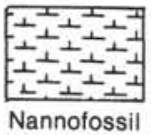

ooze

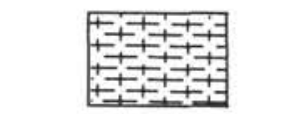

Nannofossil/foraminifer foraminifer/nannofossil ooze

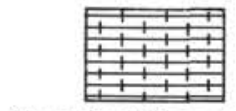

Nannofossil/foraminiferforaminifer/nannofossil chalk
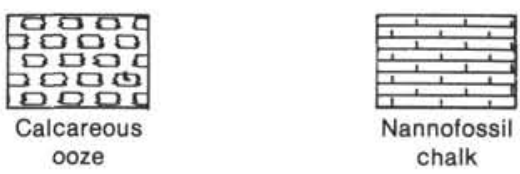

Nannofossil chalk

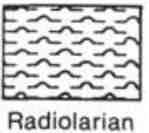

ooze

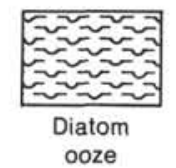

Pelagic biogenic siliceous sediments

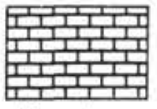

Limestone

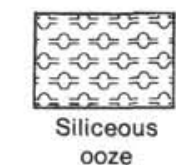

$$
\begin{gathered}
\Delta \Delta \Delta \Delta \Delta \\
\Delta \Delta^{\Delta} \Delta \Delta^{\Delta} \Delta \\
\Delta \Delta^{\Delta} \Delta \Delta
\end{gathered}
$$

ooze

ooze

Terrigenous sediments
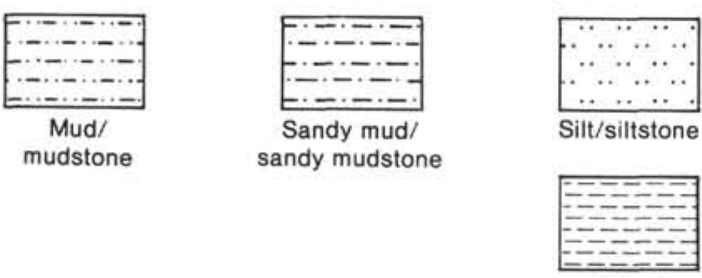

Clay/

claystone

Volcanogenic sediments
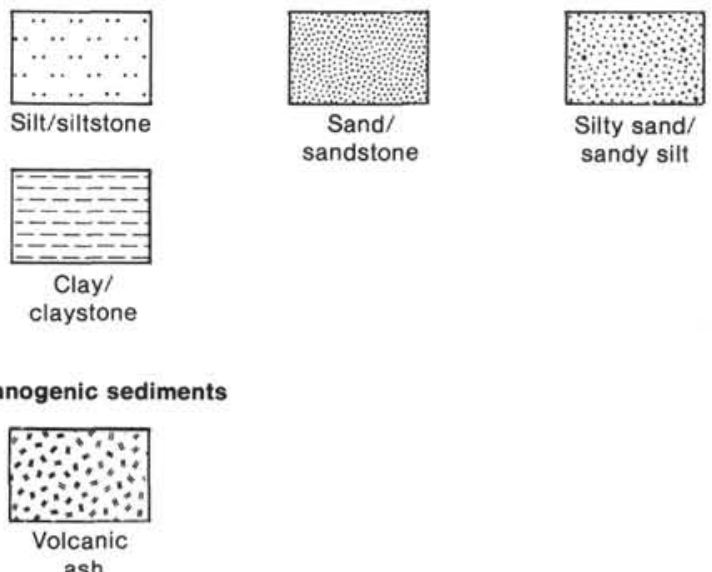

Special rock types
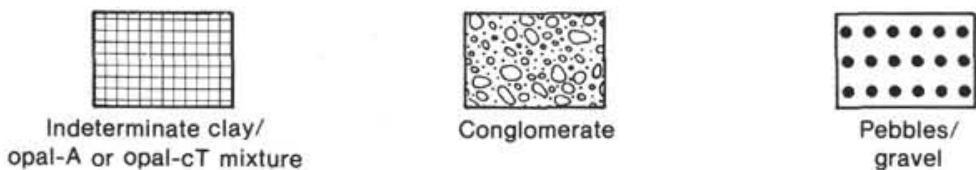

gravel

Figure 4. Standard symbols for lithologies drilled during Leg 95. These symbols are shown in the "Graphic Lithology" column of the DSDP core description forms (Fig. 2).

\section{Volcanogenic Sediments}

Pyroclastic rocks are described according to the textural and compostional scheme of Wentworth and Williams (1932). The textural groups are: (1) Volcanic breccia: more than $32 \mathrm{~mm}$ in size. (2) Volcanic lapilli: between 4 and $32 \mathrm{~mm}$ in size. (3) Volcanic ash: less than $4 \mathrm{~mm}$ in size (tuff when indurated). The composition of these pyroclastic rocks are described as vitric (glass), crystalline, or lithic. Only at Site 613 was a volcanic ash layer recovered; no volcanic breccia or lapilli layers were encountered.

\section{Biostratigraphy and Basis for Age Determination}

The Berggren et al. (1985) time scale was used on Leg 95. Zonations used for each fossil group are discussed in the site chapters.

The following letters are used on the core description forms to indicate fossil abundance:

$\mathrm{A}=$ abundant (many species and specimens);

$\mathrm{C}=$ common (many species, easy to make age assignment);

$F$ = few (scattered occurrences of diagnostic taxa);

$\mathrm{R}=$ rare (enough for age assignment); 


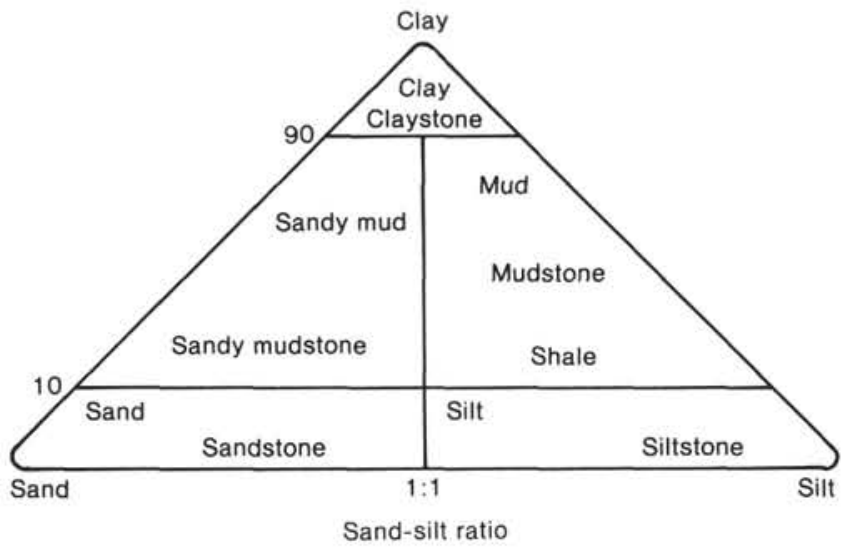

Figure 5. Triangular diagram showing classification scheme for terrigenous sediments.

\begin{tabular}{|c|c|c|c|c|}
\hline Millimeters & Microns & Phi $(\phi)$ & Wentworth size class & \\
\hline $\begin{array}{l}4096 \\
1024\end{array}$ & & $\begin{array}{l}-20 \\
-12 \\
-10\end{array}$ & Boulder $(-8$ to $-12 \phi)$ & \multirow{6}{*}{ ¿ } \\
\hline 256- & & {$\left[\begin{array}{r}-8 \\
--6\end{array}\right]$} & Cobble $(-6$ to $-8 \phi)$ & \\
\hline 16 & & -4 & Pebble $(-2$ to $-6 \phi)$ & \\
\hline $\begin{array}{l}4 \longdiv { } \\
3.36\end{array}$ & & $\begin{array}{l}-2, \overline{-1} \\
-1.75\end{array}$ & \multirow{3}{*}{ Granule } & \\
\hline 2.83 & & -1.5 & & \\
\hline 2.38 & & $\begin{array}{l}-1.25 \\
-10\end{array}$ & & \\
\hline $2.00-$ & & $=-1.0-$ & \multirow{4}{*}{ Very coarse sand } & \\
\hline 1.68 & & -0.75 & & \multirow{19}{*}{$\begin{array}{l}\text { D్ } \\
\text { ஸึ }\end{array}$} \\
\hline 1.41 & & -0.5 & & \\
\hline 1.19 & & -0.25 & & \\
\hline $1.00-$ & & $-0.0-$ & & \\
\hline 0.84 & & 0.25 & & \\
\hline 0.71 & & 0.5 & Coarse sand & \\
\hline 0.59 & & 0.75 & 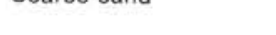 & \\
\hline $1 / 2-0.50-$ & $-500-$ & 1.0 & & \\
\hline 0.42 & 420 & 1.25 & & \\
\hline 0.35 & 350 & 1.5 & Medium sand & \\
\hline 0.30 & 300 & 1.75 & & \\
\hline $1 / 4-0.25-$ & -250 & 2.0 & \multirow{5}{*}{ Fine sand } & \\
\hline 0.210 & 210 & 2.25 & & \\
\hline 0.177 & 177 & 2.5 & & \\
\hline 0.149 & 149 & 2.75 & & \\
\hline $1 / 8-0.125-$ & $-125-$ & $3.0-$ & & \\
\hline 0.105 & 105 & 3.25 & \multirow{3}{*}{ Very fine sand } & \\
\hline 0.088 & 88 & 3.5 & & \\
\hline 0.074 & 74 & 3.75 & & \\
\hline $1 / 16-0.0625-$ & $63-$ & $4.0-$ & \multirow{5}{*}{ Coarse silt } & \\
\hline 0.053 & 53 & 4.25 & & \multirow{12}{*}{$\stackrel{0}{\grave{2}}$} \\
\hline 0.044 & 44 & 4.5 & & \\
\hline 0.037 & 37 & 4.75 & & \\
\hline $1 / 32-0.031-$ & $-31-$ & $5.0-$ & & \\
\hline $1 / 64 \quad 0.0156$ & 15.6 & 6.0 & $\begin{array}{l}\text { Medium silt } \\
\text { Fine silt }\end{array}$ & \\
\hline $1 / 128 \quad 0.0078$ & 7.8 & 7.0 & Very fine silt & \\
\hline $1 / 256-0.0039+$ & $3.9-$ & $\begin{array}{l}8.0- \\
9.0\end{array}$ & \multirow{6}{*}{ Clay } & \\
\hline 0.0020 & $\begin{array}{l}2.0 \\
0.98\end{array}$ & $\begin{array}{r}9.0 \\
10.0\end{array}$ & & \\
\hline $\begin{array}{l}0.00098 \\
0.00049\end{array}$ & $\begin{array}{l}0.98 \\
0.49\end{array}$ & $\begin{array}{l}10.0 \\
11.0\end{array}$ & & \\
\hline $\begin{array}{l}0.00049 \\
0.00024\end{array}$ & 0.24 & 12.0 & & \\
\hline 0.00012 & 1.12 & 13.0 & & \\
\hline 0.00006 & 0.06 & 14.0 & & \\
\hline
\end{tabular}

Figure 6. Grade scales for terrigenous sediments (from Wentworth, 1922).

$\mathrm{B}=$ barren.

Letters used to designate fossil preservation are $\mathrm{G}=$ good (very little dissolution or abrasion);

$\mathrm{M}=$ moderate (dissolution and/or abrasion and/or recrystallization very noticeable); $\begin{aligned} & \mathrm{P}= \text { poor (substantial or very strong evidence of disso- } \\ & \text { lution and/or abrasion and/or recrystallization). }\end{aligned}$

\section{SHIPBOARD GEOCHEMICAL MEASUREMENTS}

\section{Carbonate Bomb}

Percent $\mathrm{CaCO}_{3}$ from selected intervals were determined on board ship by the carbonate bomb technique of Müller and Gastner (1971). In this simple procedure, a sample is dried in an oven, ground to powder, and treated with $\mathrm{HCl}$ in a closed cylinder. Any resulting $\mathrm{CO}_{2}$ pressure is proportional to the $\mathrm{CaCO}_{3}$ content of the sample. Application of a calibration factor to the manometer reading $(\times 100)$ yields percentage $\mathrm{CaCO}_{3}$. Percentage error can be as low as $1 \%$ for sediments high in $\mathrm{CaCO}_{3}$; an accuracy of about 2 to $5 \%$ is generally expected.

Data from selected samples are presented on the core description sheets (Fig. 2).

\section{Interstitial Water}

Interstitial water samples were routinely analyzed for $\mathrm{pH}$, alkalinity, salinity, chlorinity, calcium, and magnesium on board ship. One sample was generally analyzed from every core; data from all these analyses are presented in the site chapters (this volume). The water samples were collected from sediments squeezed using a stainless steel press. The water was collected in plastic syringes and then filtered through $0.45-\mu \mathrm{m}, 13-\mathrm{mm}$ filters prior to analysis.

A Corning Model $130 \mathrm{pH}$ meter and a Markson combination electrode were used for $\mathrm{pH}$ measurements. The $\mathrm{pH}$ meter was calibrated with 4.01 and 7.42 buffer standards. Readings were originally made in millivolts and converted to $\mathrm{pH}$. All $\mathrm{pH}$ measurements are accompanied by alkalinity measurements.

Alkalinity was determined potentiametrically. Five-to ten-ml water samples were first tested for $\mathrm{pH}$ and then titrated with $0.1 \mathrm{~N} \mathrm{HC1}$. Near the titration end point, acid was added in $0.01 \mathrm{ml}$ or $0.005 \mathrm{ml}$ increments. Millivolt readings were noted for each increment. The exact end point was then calculated using the Gran Factor method (Gieskes and Rogers, 1973).

Salinity was calculated from the fluid refractive index, as measured by a Goldberg optical refractometer, using this expression:

$$
\text { Salinity }(\%)=0.55 \times N
$$

where $N$ is the refractive index multiplied by $10^{4}$. The refractometer's calibration was checked periodically using an IAPSO seawater standard and deionized water.

Chlorintiy was determined by titrating a $0.1-\mathrm{ml}$ sample diluted with $1 \mathrm{ml}$ deionized water with silver nitrate to a potassium chromate end point. Calcium and magnesium were measured by the method of Tsunogai et al., (1968).

Methods and equipment were checked and standardized at each site using IAPSO standard seawater. As a further check, a surface seawater sample was also ana- 
lyzed and archived. This sample was also used to test for possible drill water contamination of the interstitial water samples.

\section{Core Gas Analyses}

No evidence of gas was detected in cores from Site 612. However, minor bubbling was observed in 12 cores recovered at Site 613. These were maintained at room temperature in the core lab for 1 or 2 hours, after which the caps of the core liner bulged slightly. Gas was collected at gas cracks (observed through the core liner) using a stopcock on/off valve equipped with a needle capable of perforating the core liner. A hypodermic needle was fitted on the sampler, allowing the gas to fill preevacuated Vacutainer tubes (Beckton Dickenson Corp., Rutherford, NJ).

Gas concentrations were monitored within several minutes after collection. Methane and $\mathrm{CO}_{2}$ were measured using a Carle 8000 gas chromatograph equipped with a thermal conductivity detector. Helium was used as the carrier gas. Gas samples $(0.2 \mathrm{ml})$ were directly injected into a column (QS, $1.5 \mathrm{~m} \times 3.1 \mathrm{~mm} \mathrm{OD})$ heated to $50^{\circ} \mathrm{C}$. Quantative determination was carried out using the external standard method. Response factors and retention times were calculated using a Matheson Gas Standard (methane, $1000 \mathrm{ppm}$; ethane, $1000 \mathrm{ppm}$ ).

Ethane, propane, isobutane and $n$-butane were measured using a Hewlett-Packard 5711A gas chromatograph equipped with a dual flame ionization detector. Details of this procedure have been previously described for other DSDP sites (see, e.g., Whelan, 1979). Scotty Calibration Gas Mixture \#1 (gas concentrations of $\mathrm{C}^{1}-\mathrm{C}^{6}$ normal alkanes approximately $10-12 \mathrm{ppm}$ ) was used to calculate response factors and retention times. A large "blank" was present in the $\mathrm{C}^{5+}$ region of the chromatogram because of contamination from the $n$-butyl rubber stoppers of the Vacutainers. Compounds that evolve in this area (i.e., pentanes, hexanes) of the chromatogram were not recorded. Small blank levels of ethane, propane, and isobutane were subtracted from the results.

\section{PHYSICAL PROPERTIES}

\section{Methods and Procedures}

Physical properties measurements made on board the Glomar Challenger during Leg 95 included the following: (1) Gamma Ray Attenuation Porosity Evaluator (GRAPE) to indicate saturated bulk density, (2) gravimetric analyses to obtain accurate values of saturated bulk density and water content, and (3) compressionalwave velocity using the Hamilton Frame.

Most of the methods and procedures that were used to determine physical properties aboard the Glomar Challenger have been described in previous Initial Reports volumes (e.g., Boyce, 1976, 1977). For all measurements, the least disturbed samples representing the predominant sediment type were chosen.

All the physical properties measured aboard the Glomar Challenger (except sonic velocities) were made with the assumption that the sediments constitute a two-phase system composed of liquids and solids, that is, that the sediments are saturated with water.
The Gamma Ray Attenuation Porosity Evaluator (GRAPE) was used to assess the saturated bulk density of sediments from all the sites drilled during Leg 95 . GRAPE analysis compares the attenuation of gamma rays through a sediment sample of unknown bulk density with that of a reference sample of known density. The main problem with assessing density from gamma-ray attenuation measurements is that attenuation coefficients vary for different mineral types. Leg 95 employed the continuous GRAPE measurement, in which an entire, unsplit $1.5-\mathrm{m}$ section is scanned to provide a continuous analog record of approximate bulk density. The calibration and calculation procedures are given in Boyce (1976). Where core liners were full of sediment, the GRAPE provided reliable estimates of porosity and bulk density. Undersized cores, generally from XCB or rotary coring operations, yielded overestimates of porosity and underestimates of bulk density.

Wet-bulk density and related parameters were determined using the cylinder technique described by Boyce (1976). The measurements are corrected for salt content assuming 35\% salinity and a water density of $1.024 \mathrm{~g} /$ $\mathrm{cm}^{3}$. Data scatter results from variations in the percentage composition of sand, silt, and clay. Wet-bulk density samples were generally cubes used for velocity determination, or were taken from the half liner at the velocity measurement interval.

Sonic-velocity measurements were made with a Hamilton Frame velocimeter. The sediment samples were placed between and in contact with two transducers with a known separation distance. The Hamilton transducer has one fixed and one movable transducer so that various sample sizes can be accommodated. The separation distance was read directly from a dial mounted on the frame. Velocities were measured on split cores contained in half rounds or on sediment cubes cut from the stiffer sediments. The cube sample velocities were measured perpendicular to and parallel to bedding in order to determine directional velocity anisotropy.

\section{PHOTOGRAPHY}

Black and white photos of the cores collected at Sites 612 and 613 during Leg 95 are printed in the site chapters (those from Site 603 appear in the Leg 93 volume). In addition, both 35 -mm color core slides and black and white close-ups are archived at DSDP and are available for consultation.

\section{OBTAINING SAMPLES}

Potential investigators who desire to obtain samples should refer to the ODP-NSF Sample Distribution Policy. Sample request forms may be obtained from the $\mathrm{Cu}$ rator, Ocean Drilling Program, Texas A\&M University, College Station, Texas 77843-3469. Requests must be as specific as possible: include site, hole, core, section, interval within a section, and volume of sample required.

\section{REFERENCES}

Berggren, W. A., Kent, D. V., Flynn, J. J., and Van Couvering, J. A., 1985. Cenozoic geochronology. Geology, 96:1407-1418.

Boyce, R. E., 1976. Definitions and laboratory techniques of compressional and sound velocity parameters and wet-water content, wet-bulk density, and porosity parameters by gravimetric and gam- 


\section{A. A. PALMER}

ma ray attenuation techniques. In Schlanger, S. D., Jackson, E. D., et al., Init. Repts. DSDP, 33: Washington (U.S. Govt. Printing Office), 931-958.

1977. Deep Sea Drilling Project procedures for shear strength measurements of clayey sediment using modified Wykeham Farrance Laboratory Vane Apparatus. In Barker, P. F., Dalziel, I. W. D., et al., Init. Repts. DSDP, 36: Washington (U.S. Govt. Printing Office), 1059-1068.

Gealy, E. L., Winterer, E. L., and Moberly, R. M., Jr., 1971. Methods, conventions, and general observations. In Winterer, E. L., Riedel, W. R., et al., Init. Repts. DSDP, 7, Pt. 1: Washington (U.S. Govt. Printing Office), 9-26.

Gieskes, J. M., and Rogers, W. C., 1973. Alkalinity determination in interstitial waters of marine sediments. J. Sediment Petrol., 43: 272-277.

Matthews, D. J., 1939. Tables of the Velocity of Sound in Pore Water and in Seawater. Admiralty, London (Hydrographic Department).
Müller, G., and Gastner, M., 1971. The "Karbonat Bombe", a simple device for the determination of the carbonate content in sediments, soils and other materials. Neues. Jahr. Mineral. Monatsh., 10:466469.

Tsunogai, S., Nishimura, M., and Nakaya, S., 1968. Complexometric titration of calcium in the presence of large amounts of magnesium. Talahta, 15:385-390.

van Hinte, J. E., Wise, S. W., Jr., et al., in press. Init. Repts. DSDP, 93: Washington (U.S. Govt. Printing Office).

Wentworth, C. K., 1922. A scale of grade and class terms of clastic sediments. J. Geol., 30:377-390.

Wentworth, C. K., and Williams, H., 1932. The classification and terminology of the pyroclastic rocks. Rept. Comm. Sedimentation, Bull. Nat. Res. Council,U.S., 80:10-53.

Whelan, J. K., 1979. $C_{1}$ to $C_{7}$ hydrocarbons from IPOD Holes 397 and 397A. In von Rad, U., Ryan, W. B. F., et al., Init. Repts. DSDP , 47, Pt. 1: Washington (U.S. Govt. Printing Office), 531-540. 